\title{
RESPONSE
}

\section{An Interview with Victor Hassine Bob Gaucher}

$\mathbf{I}^{\mathbf{n}}$

$\mathrm{n}$ the spring of 1999 I organized a teleconference with Victor Hassine, currently serving a life sentence in Pennsylvania, for the "Socio-Politics of Incarceration" (honours) seminar course I was teaching. This course focussed upon prisoners' writing as an entry to reading and understanding the prison. Approximately one-half of the class had read Hassine's Life Without Parole (1996) in previous courses, and all were familiar with his contributions to the $J P P$. We were all surprised that it was possible to arrange a live teleconference with a lifer and prison writer incarcerated in the USA. As Victor commented, "we had gone international".

The arrangements with the prison administration at Albion (PA) required a set agenda of questions, which were to be approved beforehand. After providing a short biography of Victor's life, and discussing his work in class, we composed a series of general questions or areas of possible discourse. Since the topic "prison writing" did not focus upon the penal management and custom of Pennsylvania's prison system, our general questions were readily agreed upon.

On March 31, 1999, 25 (honours) students at the University of Ottawa discussed prison writing with Victor Hassine. The transcript of this (1.5 hour) discussion has been edited and reduced.

In recognition of the bilingual tradition of the University of Ottawa, Victor opened with a poem by François Villon (1431-?), "Ballade des pendus".

VICTOR HASSINE: This poem was written from the Bastille, where Villon reflected upon the executions he could observe from his cell window, and his own pending death.

Freres humains qui apré nous vivez, N'ayez les cuers contre nous endurcis, Car, se pitie de nous povres avez, 
Dieu en aura plus tost de vous mercis.

Vous nous voiez cy attachez cinq, six:

Quant de la chair, que trop avons nourrie,

Elle est pieca devoree et pourrie,

Et nous, les os, devenons cendre et pouldre.

De nostre mal personne ne s'en rie;

Mais priez Dieu que tous nous vueille absouldre!

And for those that do not speak French:

Brother men who after us live on, harden not your hearts against us, for if you have some pity on us poor men, the sooner God will show you mercy. You see us, five, six, strung up here: as for our flesh, which we have fed too well, already it has been devoured and is rotten, and we, the bones, now turn to dust and ashes.

Let no one laugh at all our miseries, but pray to God that He absolve us all.

And basically I stand where François Villon stands, and I understand now better than ever the need for mercy, not for mercy sake, but for all our sake.

QUESTION: How did you start to write? What was your motivation and intent? Has the experience/intent changed as a result of your accomplishments?

HASSINE: Everybody has a method in which they express themselves, and it's irrelevant whether you're in prison or on the moon or dying or saying your last words after having eaten some bad food in Mexico or something. But from the first cave drawings where man expressed himself and liked it and while they were running from dinosaurs and hunting they found the time to draw and to express themselves. People have found ways, even where none seem possible, and prison is like that. People have to express their experiences. 
The question isn't should people express themselves in prison because they will one way or another, whether it's through violence, insanity, kindness, hatred; the question is how will people express themselves in prison and is it possible to channel it, to get them to express themselves in an acceptable way through cave drawings or literature. My personal opinion is if you can ... and I can only share with you how I came into it ... I never thought to be a writer, I never thought that I would find myself in a position to have to write, whereas I was trained to be a lawyer and you write to a degree in that area but it's more technical writing and you're not writing about things, you're writing for people. I never thought that I would have to be a person who was a chronologist, a person telling about dying.

But all that changed when I came to prison and I suddenly found myself immersed in misery ... not only my own misery, but misery that people had experienced, including myself, troubled childhoods, injuries that they might have had, abandoned families. Prison is just one tragedy after another, and you have to express it somehow. Some people express it through anger. I chose at some point to express it through writing, and the way I did it was I wanted to share my experience with my brother and I had a hard time describing to my family what was happening. I was at Graterford at the time, and those of you that read the book, Life Without Parole, it was a very violent experience and you don't want to upset your parents and you don't want to let them know that you're living in a semi-barbaric place. So I did it through a parable, I made up a character called Slim and I wrote this short story called "The Adventures of Slim" about a young man that comes to prison and he goes through these comical experiences, but they're not really comical. And it was my way of expressing myself to my brother without having him worry about me.

That was my first writing. It was my first cave drawing, my first attempt to show the animal that I was hunting down. And that began it because my brother liked it, he read it, he understood, he didn't. The quality of writing was weak, it was poor, but it's not the quality of a writing that makes the writer a writer, it's the story, the depth of the story, it's how he writes and what he's writing about, and the meaning it had for him. He encouraged me to write and that took me out of a cocoon, and this is why I believe writing can be directed because it does help a person deal with life. It's cathartic, it makes you think about your 
environment because if you have to write about it you have to think about it; it makes you organize it because if you want to be a good writer you have to organize your thoughts. And in that organization, in that thought process, it helps you find your way.

I guess the cave drawers who drew the animal that they hunted down, as they looked at it and saw the impression of themselves chasing after it, they understood that they were hunters, and I understood more about myself in my writing than I ever believed possible. I think it is a testament to all our humanity; whether you're a criminal, a free man, a doctor, a poet, an Indian chief; our ability to write is what makes us all great, our ability to express ourselves. I think it can be directed and it needs to direct.

QUESTION: Stephen Reid stated "that writing was what brought me back and plugged me back into the world" (SSCLCA, February 12, 1998: Issue 14:8). So are you also arguing that the process of writing is in itself invaluable?

HASSINE: Absolutely, from the person who writes a letter to his lover, a letter to his boss that he hates, it does affect him. I think what happens is technically speaking the writing process involves greater portions of your brain. To hear and to listen are smaller regions of the brain, but for me to write I have to coordinate my sight with my hands, with my memory, and I have to limit it and put my thoughts into words that sometimes constrain what I want to say, so it makes me be creative. And I think in that process, it does magical things to us. It forces all our members to work together, so whether you're in prison or whether you're anywhere, whether you're going to be a lawyer or a doctor, you need to write because it's a self-discovery. And if prison is about reform, and if prison is about rehabilitation, then I think the attempt should start with at least getting everybody able to express themselves either orally or in writing, and not merely to write but to understand how to write and to express themselves in some permissible way. I think that will click in and cause a lot of positive changes.

QUESTION: Victor, a supplementary part of that question is how has the experience, your intent, changed with your writing accomplishments? I know you have a book published, we keep finding and discovering your 
writing all over the place. Obviously you've become quite prolific. Has this experience and the actual reasons you write changed?

HASSINE: On a personal level, it has actually made it harder for me to write because I find myself having to outdo the last thing I wrote and it becomes tough because what makes my writing good are the people I write about and the thoughts I write about. I mean, I don't think I'm a Hemingway in my style, but I think the stories that I have bumped into and that I've been able to retell are as great as anything Hemingway has ever written. Tragedy ... it has it all.

And so I guess I face what other writers have had to do in that you become self-critical and I don't want to write about anything cheesy anymore, I have to write something better than writing about the ... the gentleman's name was George ... I forgot, what was the title ... "Interview with David" ... the guy's real name was George. Having to beat something like that it becomes more and more difficult for me.

So on a personal level, it just lifts the bar up a little bit, and so it changes what I'm looking for, it makes me more deliberate in looking for a deeper tragedy, some greater meaning, it makes me more reflective, which in turn makes it harder for me to write. So as I write more, I come to a process where I write less, I'll become less prolific, and I've actually gotten into that, it's hard for me to find something to write about now.

As far as that part of it is an internal change. It didn't change me externally. I still see the things I do, I still feel strongly, probably more so because when I see something I break it down into words and think about writing it so I understand it better. But my life with people has changed, for example, with the penal authorities. I've had an experience, people that are in the system generally don't like it, they don't like prisoners writing stuff so you get a mixed bag, you get some staff members who have found out that a prisoner has written a book and they do not like it simply because it's a prisoner writing a book and they shouldn't do these things. And you have the Mumia case where ... in this jail system they stopped him and he had a lot of problems. They didn't like him, they didn't like the ideas, and so there was controversy and there were problems.

On the other hand, you have some guards and some staff members ... I shouldn't say guards, just staff members ... that like it, that 
appreciate it, that think it's good, they like what it's done. But they're mostly in the minority. It's not common for a prisoner so it makes you an odd person. In prison ... to survive living in a prison, the best way to do it is to be anonymous, to be the invisible man. The minute you stand out for something, whether it's good or bad, you're going to get people on one side of you or the other, and you can't handle that in prison because the guy that's on the other side of you today may be insignificant, tomorrow it may be the warden and you're in trouble. So it has put me on that level. So right now the people that know that I've written a book, most of them appreciate it in this jail. In the other jail that I was at they resented it. I actually had pressure not to publish the book, they asked me not to ... to decline publishing it. And the minute they asked me to decline I insisted on publishing it.

The funny part is I've just recently been in teleconference with a Professor from Troy University. He was at the time ... well, this was about month ago. In 1996 ... '95, '96 when the book was first being published, he was the administrative assistant to the Commissioner of Corrections, which to me is the administrative assistant to God. He was the man that could do anything in the prison. And he was against it, he was against the book. The Commissioner was for it and assigned him to handle whatever clearances I needed to publish the book with Professor Tom Bernard. He resented it. I met him after permission was granted and spoke with him, and I'm not guessing that he didn't like it, he told me he didn't like the fact that I had, he didn't like me because I was a jail litigator. I had sued this institution many times and I was looked at as a thorn and they didn't know how I would slant it or tilt it, they had no idea, and they didn't like the idea and they didn't like an "inmate" writing a book to give him notoriety.

Well, he leaves the Department of Corrections, becomes a Professor, and this book that he didn't like is now required reading for his students, and where he didn't like talking to me in prison, he goes through the trouble of getting on the phone, calling and having a teleconference to get all the information that he could have had for free or without any problem while he was at the Department of Corrections. His whole view turned around, his whole perspective turned around. My being in prison didn't change, the goals of prison didn't change, the contents of my book didn't change, but by virtue of the fact that he was now a Professor and had to analyse it critically suddenly he found 
himself supporting my book where he originally had stopped me or tried to stop me from publishing it. So that's the kind of weird things that happen in prison.

Oddly enough, most prisoners dislike the fact that I wrote a book because it sets me apart and it creates a lot of jealousy. Most prisoners can't read so they can only guess at the content. When I first came to this jail, I had a problem with some prisoners who believed that I was "a snitch" for having written a book that told about prisons because how could you write about prisons and not tell on somebody. These people are functionally illiterate and you just have to deal with that.

When I was at Rockview, the last prison I came from, two prisoners sued me or tried to have me charged in court because I wrote the book and one of the reasons for doing that was because they thought that I was somebody that was making money from the book. Jealousy ... there's a reason why jealousy was the first crime committed in the Bible, it's because the most common negative fact of human beings is jealousy. It causes a lot of problems and you see it most in prison.

Outside, it's been very warmly received, surprisingly, not only by Professors and criminologists and experts, but also by Departments of Corrections and staff members who believe that the book should be used as a textbook. It has been suggested to my publisher that the book be modified to be used as a workbook for people entering the correctional field. So I've gotten a lot of outside support.

The one thing I didn't expect was the Prison Society who are a non-profit group in Pennsylvania that kind of looks after men in prison and makes sure the prison system treats men in prison properly, I have worked with them closely and I have been very close friends with all of the members, and when I sent them the book I thought they would love it. But they didn't like it because they said that the book tended to demonstrate or give the impression that people in prison were sub-human or bad people, that it didn't give the good stuff, how voluntarism is really great and how volunteers make a difference and how wonderful people they are at the Prison Society. The problem is what it meant for me, they wanted me to write about the exception to the rule and omit the rule of prison at Graterford. When I wrote them we got into a debate about that because their view of prison as volunteers was very different than my view of prison having lived in the same place. And whereas if I were to write a book about how wonderful volunteers 
are and how great, I would have been lying. I would have been lying to the majority. That was kind of weird to me, that the people that I thought would support me were against me and then years later the people that were against me support me.

QUESTION: Just let me back up a little on that, did your book go through prison censorship, before you were allowed to deal with the publisher?

HASSINE: If you read the book, you found out that I wasn't looking to publish a book. I was trying to just write short stories and send them out to whoever would listen. It was my way of putting a little note in a glass bottle and sending it afloat. Dr. Bernard from Penn State University, a criminal justice specialist, saw it and without telling me he sought to get permission from the Department of Corrections; which was the Professor Thorsley who I just discussed who is now the Professor at Troy University, and Commissioner Leeman who is now in Washington State, the commissioner of Corrections there.

I didn't know this was happening. Now, the law in America ... I think you may have the same law, referred to as the Son of Sam Law. The Son of Sam Law only affects writing that discusses your case. So if you notice, my book does not mention much about my case because if it did, it would have been subject to the Son of Sam Law and subject to censorship. The way the Department of Corrections in Pennsylvania deals with it, it was discussed and decided in the Mumia case. They had a general rule that you are not allowed to make money or enter into a money-making enterprise while you're in prison. Therefore, Mumia Abu-Jamal wrote a book and collected the royalties to pay his lawyer, they considered that entering into a business, they gave him misconduct and they sanctioned him for it. The court ruling was that the Department of Corrections can sanction you for that but they cannot stop you from writing. So that's the rule.

I could have published a book without permission of the Department of Corrections. In turn, they could have given me a class two misconduct, which is like a misdemeanor, and given me three days in the hole, and then that's it, and I could have published the book.

QUESTION: What about the proceeds from it? 
HASSINE: I gave the proceeds away ... but technically I could have kept the proceeds. The Son of Sam Law does not disallow you from earning money from a book that you do not discuss your case because you'll not benefit from your crime. Nothing in my book discusses my crime. But I would have run afoul of the Department of Corrections rule against conducting a business. But I had never intended on making money from a book and I never even looked into it and I would have published it anyway and I just gave the money away, and it took away any objection they could have had. Any prisoner can write a book and give his money away as long as he's not writing about his own case. And I think every prisoner should do that. I think there's a need, I think there was a backlash in the 1980s against Jack Abbott. I think editors and publishers were afraid to trust prisoner writers, and I think in turn a lot of prisoner writers just don't want to do it. I think people should write for the sake of writing, give the money away and get the story out.

QUESTION: You have published articles in academic books and journals, which are not "commercial transactions". Have you experienced censorship or such difficulties in these endeavours?

HASSINE: Absolutely. Everything that's written in prison for use and circulation within the prison is censored. They make sure they read it. When you write ... for example, they have a contest when you write prison poetry. The jail system has a contest in which you can win $\$ 25$ if you win or $\$ 50$ if you win first prize, but they tell you right off the top you cannot write anything that's against the prison or against the prison system or against a particular guard or staff or stuff like that. You can't write anything that can incite dissent. Prisons are about control. They're not about exercising freedom. The concept is if you want freedom, stay out of prison. That's basically what they tell you. When you come in here we're going to censor you, we're going to tell you what you can write, we're going to tell you what you can't write and we're going to watch everything you do.

As far as my writing about my own story and publishing it outside the prison, I could do that. They can't stop it but they can punish me for it. And their theory is if you want the freedom that you suddenly discovered that you need in prison, get out of jail, do it then, don't do it here, because their main and only goal is to keep the prison intact, 
operating and to keep you where you're at and quiet. That's the only intent of a prison. All the guards, all the medical staff, everything these days are for that purpose, to keep two million Americans or whatever the number happens to be in prison, contained safely and appropriately with no riot, no escapes, no injuries. That's the main goal. So absolutely there's censorship on everything.

QUESTION: Victor, what are the benefits of writing in prison? Is it therapeutic?

HASSINE: People are going to express themselves. If they're not going to write about it or draw on the walls about it, they're going to beat somebody up, they're going to express themselves with their fists, they're going to express themselves through cursing, they're going to express themselves through suicide, they're going to express themselves through tattoos. They must express themselves.

Writing is therapeutic. It is something we love. It is something that has separated us from other animals and other life forms, it has made us unique, it has made us able to live the experience of our fathers and talk about places that we've never been before and understand them before we've been there.

If you don't have writing in prison, if you don't encourage it through educational means and you don't tell a guy if you're angry write about it, curse about it, just don't beat a person up; if you do not give them a way to express themselves, give them the ink to write on the walls, the expression is going to come out. People don't understand that riots are a form of expression, they're an art form, it's people saying something. The fact that we don't choose to listen doesn't mean they're not saying anything, they're saying a lot. We tend to look at it as just violent, random, it's not, it's an expression of anger, of frustration, of pity, whether it's self-pity, whether it's deserved pity, whether it's people that deserve it, they are going to express themselves because we're humans and it's needed. And you might as well give them the tools and just fix the walls and paint over the walls than have to deal with it in human writing of blood on the walls, whether it be their own. Even if in prison the only violence people do is kill themselves, is that what we want to do? As a society, do we want to encourage suicide? You have to take a look at the bigger picture. 
I think writing is under-utilized in prison because most of the people in prison are functionally illiterate. So in order to get to the writing stage, you must teach people how to write ... or ... I like what they do in England and Europe, plays ... encourage people to act, to perform. The Greeks did it. Most Greeks could not write, but they all put on theatre and drama and it caused the birth of a civilization, of an empire.

Certainly if they can do it, we can do it, but it's not considered. I don't know why. I don't know whether they don't think we deserve it or they don't want to pay the money, but I think in the long run it's not only therapeutic, I think from a correctional standpoint it creates more harmony and it makes it easier to maintain people, to control people if you're dealing with their expressions in writing and in theatre than if you're dealing with their expressions with a fist or a violent act of some sort.

Apparently in Canada and America, it's not well thought of, but I did stage a play here. And let's understand people. If you're going to go into the people business, if we're going to lock two million people up in America and heaven knows how many in Canada, that's a lot of people. You're dealing with small countries. You're dealing with ... well, not countries, definitely a State ... you have States in the Union that don't have two million people. You have whole provinces in Canada that don't have two million. You have to understand that you're dealing with people and you have to ask yourself what kind of people are they. Well, the majority of people in prison are functionally illiterate. Well, is that a coincidence? Well, since we don't believe in coincidences, you know, we've invented so many things that there's no such thing as a coincidence, there must be some relationship between coming to prison and illiteracy. And there is because if you're illiterate nowadays in this technological marvel of a life that we live in, you can't function, so where else can you go but to a place that will feed you, house you and keep you alive? That's what prison is and that's why you're catching so many people that can't function. The question is once you bring them to prison do you just want to punish them or do you want to make them functional? Well, you get tired of punishing people after a while, and if you punish somebody forever it's stops being punishment, it becomes a way of life. At some point you should try to make them functional. Well, how do you make people that are functionally illiterate functional? Well, 
the reality is some people learn by reading, some people learn by watching, there's some people that will never learn how to read, their computer in their brain doesn't work that way. But if they look and they watch and they have a great memory, they'll be able to catalogue every vision that they see and understand more from what they see on TV than anything they could ever read. A lot of attention deficit kids are like that, they're only attention deficit when they're reading a book or having to talk to somebody. If they're watching a movie and listening, all of a sudden you can't take them away from TV.

Knowing this to be the case, I think corrections in Canada and America are fumbling the ball by not encouraging theatre troops in their prisons to encourage people to express themselves in a way that they feel comfortable doing. Who's to say that writing is the best way to do it? I believe that within 50 to 100 years writing is going to be passe, everybody's going to be doing digitized thinking, speaking monitors. Who's to say that you should reach out to these people in that kind of form when you have 60 percent of a population who can't read. Fine, let them perform it. Let them learn their lessons by watching them. Let them learn their lessons by having books on tapes pumped into them. Let them get those experiences in a way that they can understand, and that's prison theatre. And I think it needs to be done and I think it's not done enough.

The Greeks by no means were literate people. If they could form an empire strictly using theatre and talking about their ideas in open forms, then certainly the idea can work in prisons, and it needs to be done and it's cheap. You're spending $\$ 25,000$ a year in this State on prisoners. It would cost next to nothing to have an actor come in here and teach people to perform and allow them an opportunity to express themselves. Everybody wants to draw in a cave, give them the tools.

QUESTION: I have a supplementary question to that. In Canada, prisoners, especially Aboriginal prisoners, have long exhibited an affinity for visual arts. From my own experiences I would suggest that an extraordinary proportion of prisoners have the ability to draw, to paint, or express themselves in some visual art form. Is that your experience in the USA as well? 
HASSINE: Absolutely. Absolutely. When I was at Rockview, I took a course, they have an architect who teaches drafting, architectural drafting there. And I took the course and after I took the course I ended up being his aide, his assistant. And one of the things I talked him into doing was to opening up his course to people who couldn't draw. Before I got there and started working with the man, you had to test into the course, people would have to test and the test was like a seventh grade test, but in prison a seventh grade test might as well be the LSAT. Only people that could pass that test got into the course, so most people that took the course were literate; generally it was more white than minority, richer not poorer; it was not reflective of the prison population. Those guys ended up in the program, and we already know how those people are going to do. If they can already read and already draw and pass the test, it doesn't do anything. And I convinced him to do it the other way around, to take them as they came. He was a little shaky about it, but he took them. Soon the class reflected the prison, it was majority minority, most of them hadn't graduated from high school, they had to take an entrance exam test, but the test was much easier. And the amazing part is, after nine months, people that had played hooky, that were truants, that did more stealing pens and pencils than drawing, all wanted to be architects and all could draw much better and had more discipline because they could see the product of their labour. As they drew they could see something coming alive and they felt attached to it. Soon we couldn't get them out of there. These were people that ducked school all their lives, suddenly we had to order them out of the area because they wanted to stay and draw more and draw more and draw more. And the worst thing that happened is they used to fight over who would stay for the second nine-month period ... there were two nine-month periods.

And so it does work. Creativity. They have a program here called art therapy, but based on the theory that art has a therapeutic value as well as an artistic value. Everything that engages the human mind to self-express, to identify himself as more than just one of the cogs in the wheels and that makes him unique is worthwhile and is something that not only people in prison are missing but people out on the streets are missing. That self-actualization through creation. And that's what artwork does, theatre does, writing does, drawing does. That's my experience. 
Professor GaUcher: Maybe we can move over to the second page with questions on the process of writing in prison.

QUESTION: On what basis do you choose topics?

HASSINE: That's the hardest part, that's gut instinct. Since I'm in here, what I usually do is something that strikes me as something that most people wouldn't know about prison, so when I write about prison I don't want to write what you already know, what 9,000 textbooks are written about, I want to write the juicy stuff. I want you to read it. I want you to understand prison better, not as a cliche, but as a real life experience. So generally, since we're all human beings and we tend to normally react the same to tragedy, when I find a particular tragedy or find a pattern of behaviour or a pattern of doing things that I find weird or absurd or interesting that I didn't know about before I came to jail. Because I stood in your shoes, I was a student, so it makes it easier for me to think what did I know back then, what would I consider fun to have read if I had read it. The stuff that I read was just as dry and unpleasant as the stuff that you're reading now. I mean, it was really boring and put me to sleep. So that's what I use. And so what strikes me loudest are the tragedies.

Again, prisons are houses of tragedies. People don't come to prison because they want to. Maybe a handful of people come in here because they're outside on the street and they say I like prison, I like the food, let me go meet a couple friends there and do something good. People come to prison because of some chain reaction of tragedy after tragedy in their lives that somehow landed them in a situation that put them in jail. If you grab any person at random, take them to the side, ask them, "What did you do?" "I'm a burglar." And then you take them back through the chain reaction of causation, you would find most of the time some kind of tragedy, broken family, assault, abuse, juvenile centres, having been raped, having ... now, that's no excuse, but excuse is a moral question. It's a reason, it's an understanding. And so when you're submerged in this kind of tragedy, you have so much to write about. The question is ferreting out all the things that you think would be the most interesting and the most valuable. That's the hardest part, and that's what I do, I listen, I talk, I think, and I go by my gut and what affects me and what shocks me. And that's what most people do, and that's what you're 
seeing, the things that have shocked me. And there's going to be more. I'm working on the third edition.

And that's how I pick it. I have written about HIV because at the times I wrote about it it was relatively new and nobody talked about HIV in prison. And HIV in prison is very very important because if you don't contain it in prison, you have two million carriers that will bring it to the rest of the country and bring it to its knees. That's the reality of HIV. And it's not the HIV infection that's going to get you, it's the stuff like tuberculosis that you get, the opportunistic diseases. And historically that had been the case with prisons, the fact that it spreads diseases, and we seem to have forgotten it, we imprison more people and we think that our medicine is going to save us from anything that prison can produce. And it's just not true. Madness. This movement toward putting people in jail for 23 and 24 hours a day, it leads to madness. We've known it for decades. We knew it when the Quakers first started it. Charles Dickens wrote about how it created madness. But we seem to have forgotten that, it's come back and nobody's writing about that. Although last week in the States on the 20/20 program Geraldo Rivera talked about madness in prison. So it is coming out now. But nobody's writing about it because think about it, if you're mad you're not capable and need somebody else to write about it ... or read about it. So it's hard to write in prison now because you don't get out as much, it's real crowded ... it's real busy in prison. And it's tough to write, it's tough to find the time or the place or the incentive to write. They keep you pretty busy in here.

QUESTION: Noting the ethnographic quality of your writing, how do you separate yourself, as a writer, from your own situation as a prisoner? What I'm getting at, Vic, what I find amazing about your writing, is your apparent sense of distance that allows you to be the observer.

HASSINE: That's a good question, that's one of the reasons I started off with François Villon. He did the same thing I did. I had experience in the criminal justice field, I mean, I was working as a lawyer and I worked in the Manhattan DA's office and I had touched it here and touched it there, and I had an idea of what the prison looked like from the outside. So in order for me to write from the outside, I just placed 
myself to a point that I was before I came to prison, and I asked myself what would I have seen, what would I have not wanted to see. You have to detach yourself. The hardest thing in the world is for a person who wants to help the poor to have to live amongst the poor. You see so much misery, you see so much strife because poor people can be nasty, and if you have to live amongst them to help them, you will find that most people wouldn't. That's what makes Mother Teresa so special, she helped them and lived among them. That's why they're going to saint her. I'm not a saint, and it's very difficult for me at times to live in this environment and still write objectively without hate not only for guards but for prisoners, for the ignorance in this place, ... for the thievery.

So what I do is I do detach myself and I have to or else I would have so much hate because being crammed in this prison in these small cells with so many angry and hurt people and injured people makes you hate, and you can't write objectively with all that hate in you. And so part of my pleasure in writing is that in order to write objectively I have to remove myself from prison. And although I don't remove myself physically, my mind is removed and then I'm a little more free, I'm a little less hateful, and I can better deal with it. And so there's an actual separation from mind and body and it has to take place, at least for me. I don't know how Jack Abbott did it, but that's how I have to do it.

QUESTION: In opposition to the monster image of prison writers "recounting their gruesome tales" that tends to dominate official discourse on the subject of prison writing, Stephen Reid argues that "it takes heart" and social sensitivity to write.

HASSINE: Absolutely. I was watching a program that had Lucas, the guy that did Star Wars. Are you guys familiar with him? He was talking about writing, and he referred to writing as allowing yourself to bleed on paper. Every time I write a story it is very very difficult for me to do that because every edit I put into it I relive it, I feel it. That's where the courage has to do. Not only ... I mean, I don't like the fact that I have to confess to you that I live in a sub-human world and at times I have to live like that. That's obviously the message from what I wrote. I mean, I wasn't saying that I was the only guy that wasn't acting like that, I lived in Graterford. You couldn't be human and survive there. You had to act like a convict, and I had to relive those things. And the tragedies 
that happened. And that's where the heart comes in. Not everybody can handle looking at themselves as they are where they are when they are. It is a hell of an experience. And it's a tough one. So you have to be brave, very brave, and you have to allow yourself the ability to bleed on paper because with every word I do I bleed.

Professor Gaucher: We have about fifteen minutes.

HASSINE: I liked your questions. Of all of the other questions that I've received (I have done about five of these conferences), these are the best that I've had. One noticeable absence is questions about my crime, and I appreciated that because I think that's irrelevant. I think we should have this discussion whether I'm the best inmate or the worst because what needs to be done needs to be done for the best or the worst. So I appreciate the fact that those questions weren't there.

QUESTION: Having written fiction, plays and poetry, how do you see yourself as a writer, what do you most enjoy writing? Where do you get your joy?

HASSINE: I've not talked to you about this, so it's to the benefit of your students. I've tried like heck to have my fiction published. But for some reason, publishers and academics that I send it out to just send it back to me and said, "Leave the fiction alone. Get back to the non-fiction." And it's hurt my feelings actually to be honest with you. I like to write fiction. I guess the reason I like to write fiction is I can write stories and detach myself more and not feel as painful about writing it. It enables me to talk about people in the third person and so I have less of a direct experience on the experiences I write about and it also frees me up to talk about things that I might not be willing to talk about in the first person. I'm trying to write fiction. I'm trying to do it better, trying to find out why I'm not writing it as well or can't, but that's where my heart is. I want to write fiction. And probably the reason I want to write fiction is because it's so painful to write non-fiction, I'll be honest with you, because I'm not that brave and I'm not that strong and it does hurt. And when I reread the stuff it does bother me. 
PROFESSOR GAUCHER: It's quiet now.

HASSINE: I don't want to put you guys in tears. Let's bring up some happy questions. How do we make beer in here or something.

QUESTION: Has/does your university education and legal training affect your experience of incarceration? Did it prepare you in anyway for this experience?

HASSINE: It made it worse. When I came to prison I had a good understanding, better than most in prison, of the system or how it functions from the outside looking in. The problem is it doesn't function like that from the inside looking out. It just doesn't work like that. And then when you try to say, "Wait a minute. The Constitution and the laws don't allow this," and you have somebody come up and tell you, "Well, the laws don't have to have that, we can do what we want to," it offends you more than it would if I didn't know about the law and I'd always been subjected to the heavy hand of the law in that manner.

I'll give you an example. After I got assaulted in Pittsburgh and I got transferred to Camp Hill, another prison in Pennsylvania, travelling with me was a court order for certain medical care. The Judge at the time directed the Department of Corrections to provide me with a very specific medical therapy treatment, wrote it down, signed it, the Department of Corrections swore and it was a legally binding contract. Well, I get it to Camp Hill, 200 miles away from where the contract was signed, department head comes in, tells me he's going to put me immediately in the hole, no medical treatment. I show him the certificate. He says, "That's not worth the paper you wrote it on. Judges don't understand prisons. We run this. You don't like it, it's too bad." Fortunately, I had one phone call to make. I called my lawyer, and the Judge convinced him otherwise. But when you have an experience like that, it shakes your foundation.

So in that respect, understanding the system and believing in it ... believe me, I believe in the American system ... I like America. I've been to Canada, I like Canada, but I like America. I like living here. It's better than ... I came from Egypt. It's better than living in Egypt. The problem is there's a far cry between its stated goal and the reality of its enforcement and especially in prison. 
So it affected me in that way. The fact that I came from a humble origin, that I came to this country a refugee and worked my way up and had felt the bite of poverty as well as the champagne of success, it gave me a broad spectrum to draw from experience-wise. But it was more painful for me going from a good life to a bad life than it was going from a bad life to a good life. And that's the problem.

When I came here, incarceration was significant for me because I gave up so much more. I gave up a lot. And that bothers me. But the good part is it enabled me to find myself, it enabled me to escape, mentally, physically, it enabled me to do something meaningful in my life even though I'm in prison. Many people come to prison, die in prison and never experience meaning in their lives. If I were to die tomorrow, I wouldn't like the fact that I died in prison, but I can't say that I haven't contributed to life in some way, haven't done something meaningful. So therefore, I have a limited amount of happiness that I've been able to grab for myself, and I couldn't have done that without university education or literacy or understanding which lent to my understanding of my need to have that kind of meaning in my life and then to the ability to go out, find it and grab it and make it happen.

HASSINE: Any questions unrelated, just regular quick questions I can give quick answers to?

QUESTION: Victor, do you feel very much alone? Have you made comrades with the other prison writers or ... I'm just wondering if you correspond with other prison writers.

HASSINE: When I got published I was president of the lifers group over in Rockview and I ran a writing contest much like the Pen Writing Contest and tried to encourage prison writing. I wanted to form a writing community, but prison teaches people, especially when you have a lot of long-timers, to be solitary people. You don't share. If you share, somebody will take it away, somebody will tell on you, the administration will find out and find some objection.

So the problem is writers want to share and it would probably enhance the writing and make it better because when I read other prisoner's writing it encourages me to write. It's kind of like a competition. You learn new forms and what works better. But the way 
prisons are now with so much informing going on ... that's how prisons run, on the informant system now ... writers can't be open about what they write, even if they write about normal things, good things that have no objection. They're worried about it getting stolen, being told on, being misunderstood, being destroyed. So it needs a community but it's not happening.

Also, at one time prisons used to encourage prison community writing. They discourage it now because they're worried about people writing and encouraging the population to want to know more about prisons. They don't want to go through the sixties again. They want prisons to be anonymous, they want what they do to be out of the limelight, and you can't do that if you have too many people writing about their experiences.

So on the one hand, I'd like to see it and if I saw one I would definitely get with him and we would talk. But on the other hand, the likelihood of two writers in prison talking about it now would not exist because we would be at odds, we would be worried about who the other person is and there's a lot of paranoia in prison, and it's a shame. What needs to happen is the administration of prisons needs to encourage this kind of stuff and encourage writing communities, encourage that whole writing process and not worry about the sixties because the sixties weren't as bad as they are now. We didn't have two million people in prison in the sixties. So no matter how bad it was, it couldn't have been as bad as it is now.

QUESTION: How in the world did you get involved in this book on prison theatre? Maybe you can tell us how that came about. [HASSINE WROTE PREFACES FOR THEATRE SECTIONS IN PRISON THEATRE: PERSPECTIVES AND PROCEDURES (I 998), J. THOMPSON (EDITOR), London: Jessica Kingsley Publishers.]

HASSINE: Interesting story. When I moved from the Pittsburgh prison to Rockview, I was moved to a prison that did executions, and I was against the death penalty even before I came to prison. And all of a sudden we ended up with a Governor whose promise on coming into the Governorship was that he would execute. So I find myself in what I call the slaughterhouse because I was walking every day in a death house and it gave me an uneasy feeling and I didn't like it. And at that 
point I had done some writing and I figured it was time to write, and I wrote a play about the death penalty. I sent it to you, Bob, it's called Circles of Nod. And so I wrote the play, sent it to the warden up here, I sent it up to Pen Writing. It won an award. I sent it to the warden at that prison, and he was against the death penalty. So he did like the fact that I objected to the death penalty, but he liked the play, so he allowed me to stage the play in the prison using a prisoner cast and crew and being directed by a Pennsylvania University former drama instructor. And it was very very successful.

As a result, I sent that off to ... how did I get ... somebody sent me the name and address of a group of people that were doing research into prison theatre out of England which is very big ... where were they at ... Manchester, England, University of Manchester in England. And I sent them a copy of the play and they responded and it was a Professor Thompson who wrote me back and we entered into correspondence and he sent me stuff that the British were doing and I sent him stuff that I had done, articles. I started sending him a bunch ... I wrote a couple other plays and we talked about it. He ended up doing a sabbatical in the United States in Texas. When he came to Texas he began writing a book, and he asked me to write something for it. So I wrote about my experiences in producing the play in America. He liked it so much he used it as the introduction to three of his chapters. And I think that's the book that you have.

PROFESSOR GAUChER: That sounds like it.

HASSINE: So you never know where your writing's going to end up. I had no idea when I wrote the play that it would end up in England or anything like that, but it worked out and that's the power of writing, it is why we need to do more of it. It is the strength, it is setting a ripple in the ocean and not knowing where it lands. It is a tremendous power. We need to use it. I can't imagine, no matter how bad somebody writes or how terrible it is, that you should ever discourage it. We can deal with bad writing, we can't deal with bad lives.

QUESTION: In the short biography you provided, you note that you received an "inmate of the year" award. I have never heard of such a thing. What is it? 
HASSINE: And you should have, shame on you. The Prison Society awards it once a year ... it is really a big thing for prisoners. I actually got a half a day furlough, they actually let me out. I had two guards on either side of me but I was in street clothing, I had a tie and jacket on, I went out and I had a little luncheon, I gave a little speech, my folks were there, my friends and family were there, and for six hours I was a civilian again. Then the shackles and handcuffs came back on. But it is a big thing here. And once a year they pick an inmate, and they picked me that year because of my litigation in the Tillery case which was a landmark case in Pennsylvania which found Western Penitentiary unfit. It caused a lot of changes, caused me to be transferred. It caused a lot of changes. They honoured me for that because it took a lot of ... I got assaulted in the process, transferred. It was a terrible experience. But it was all worth it to be able to be with my family for six hours as a normal civilian, as a member of society, and it felt good. That's a big thing here.

Professor GAUCHER: What's the time element?

HASSINE: He said we're entitled to one more follow-up question. Any question will do.

Professor GaUCHER: How about you leave us with a question?

HASSINE: Okay. I'll leave you with a thought and not a question.

Professor GaUcher: All right.

HASSINE: All of you are going to enter some ... most of you are going to enter some kind of prison career, either as a lawyer or correctional officer or policing or even if you're just a citizen that votes on an issue, and what I'd like to say is I don't want to ... I'm not here to try to sway you into my way of thinking. I want you to think critically about what you're doing, about the policies that are happening in prisons, think critically. Don't do what's easy, do what's right, and then determine what purpose do you want.

One of the things that is gone out of prison is that prisons don't have a purpose. Housing or holding human beings isn't a purpose. 
Whether you want to beat them or fix them, that's a purpose. If you want to beat us, then beat us. If you want to fix people, then say you want to fix them. Pick a purpose. But I want you to use reason in dealing with people.

When François Villon was sitting in the back field and he's watching these people hang for the first time, he was a nobleman and he had heard about them and he talked about it and probably laughed at a few as he walked by them ... suddenly he's looking at them through the windows and visioning himself being the next guy there because that's how they dealt with overcrowding back then. They just put you on the gallows and they were getting mighty crowded.

So understand that it could be you, it could be a friend, it could be somebody. But more importantly, if you want to do what's best for the country, whether it be Canada or the United States, you can't act in a way to be mean just to be mean. If you're going to be mean, have a purpose to it. The worst thing in the world is if a guy punches you and doesn't tell you why he's punching you. Please, don't add to my misery by not telling me what you hope to gain by it. And if you don't know what you hope to gain by it, then maybe you shouldn't punch me, maybe there's something else you need to do.

And that's what I want you to do. All prisoners are not scarred, toothless people looking to jump on you and kill you. They're human beings. They have good to contribute. All of us have good to contribute. The question is can we pull it out of them. That's the purpose, that's the question. And if you think you can do it through beatings, then say you want to beat us. If you think you can do it some other way, then do it some other way. But think about it and don't just do it because everybody else is doing it.

God bless you. Good luck to you. And au revoir.

Professor GAUCHER: Thanks a lot, Victor. 